\title{
Effects of Pivot Windows and Wing Walls on Single Sided Natural Ventilation in Rumah Susun (Walk Up Flat)
}

\author{
Nilla Ardya Prihatanti, Sri Nastiti Nugrahani Ekasiwi, and Ima Defiana \\ Department of Architecture, Institut Teknologi Sepuluh Nopember, Surabaya \\ e-mail: nastiti@arch.its.ac.id
}

\begin{abstract}
Rumah susun (walk up flat) are one of the buildings that rely on natural ventilation. However, the application of natural ventilation in rumah susun (walk up flat) in urban areas is influenced by tropical climate problems such as high temperatures and low wind speeds. The design of the openings in the facade has not been able to distribute air into rooms properly. In addition, the layout design makes single-sided natural ventilation the only strategy possible for double loaded corridor type flat. This study aimed to determine the effect of a combination of pivot window designs and wing walls in directing and distribute air into room. The study was conducted in two stages, that was field measurements and experimental with Computational Fluids Dynamics simulations. Simulations were conducted on a combination designs of wing walls and pivot window with $45^{\circ}$ and $90^{\circ}$ opening angles to determine their effects on the distribution and indoor air velocity. The combination design of wing walls and pivot window created a pressure difference so that it could increase indoor air velocity under both oblique and parallel to the opening. In the direction of the wind that was not oriented to the openings, the combination of wing walls and vertical pivot windows with $90^{\circ}$ opening angles increased indoor air velocity up to five times in the corner room. While the $45^{\circ}$ opening angle increased the indoor air velocity up to seven times than base case condition in a middle room.
\end{abstract}

Keywords-Opening Angle, Wing Walls, Indoor Air Velocity, CFD Simulation.

\section{INTRODUCTION}

$\mathrm{N}$ ATURAL ventilation is very important for human health and well-being life [1]. Rumah susun are one of the buildings that rely on natural ventilation. The problem of natural ventilation performance in rumah susun has been widely discussed. The results show that the problem of natural ventilation in flats is influenced by tropical climatic conditions, facade design and building spatial design. Tropical climate problems are related to the different acquisition of winds in room units with different floor and locations $[2,3]$. The problem of natural ventilation in rumah susun has not been supported by the right facade and layout design [4]. The layout design of the double-loaded corridor type caused the main air circulation from only one side [5]. In addition, habit of the occupants who prefer to open windows that were oriented to the outside space became a consideration that makes single sided natural ventilation is the only possible strategy applied in rumah susun [6]. However, the results of measurements in the field show that the indoor air velocity is very low, so that affects the air quality in the room.
Referring to these problems, it is necessary to design the facade of a flat that is able to consider the acquisition of wind in the unit space at different heights and locations. In the context of single sided natural ventilation, existing studies show that the application of vertical and horizontal pivot windows has the best performance in distributing airflow into rooms due to the pressure differential created between outdoor and indoor [7]. Other studies have shown that window design with a flexible opening angle has a positive impact on thermal comfort and air quality in the room [8-9] Meanwhile, the application of the wing walls design can direct and distribute air flow into the room properly [10]. The study about design combination of pivot windows and wing walls is needed to determine its performance in directing the airflow into room.

Reviewing the problem, this study examined and explored the combination of pivot window designs and wing walls on single sided natural ventilation. This research was conducted in a case study of rumah susun in Surabaya city. The performance of a combination of pivot window designs and wing walls was reviewed in units with different locations. This study examined the application of the design of wing walls and pivot windows and with different opening angle to indoor air velocity and air flow distribution in a room.

\section{II.METHOD}

\section{A. Case Study and Proposed Models}

The study was conducted in a case study of Rusunawa Siwalankerto II building in terrain roughness sub-urban conditions. Rumah susun Siwalankerto II is a result of typology study in Surabaya. Rusunawa Siwalankerto II is a five-story building with floor height is 3 meters. This rumah susun is a double loaded corriodor type. The building form of rumah susun Siwalankerto II has a geometric mass with openings that allow only from one side of the building. This rumah susun has residential units with an area of $24 \mathrm{~m}^{2}$ and facades with wing walls.

The facade of this building is a combination of architectural elements, such as windows, balconies and wing walls. The entire window in Rusunawa building is a top hung casement window type window. Meanwhile, wing walls's width was $40 \mathrm{~cm}$ and located between two rooms. Case studies, researched rooms and experimental models can be seen in Figure 1.

Rumah susun building form is long-shaped so that the distribution of pressure on the surface of the building will be 
The $6^{\text {th }}$ International Seminar on Science and Technology (ISST) 2020

July $25^{\text {th }} 2020$, Institut Teknologi Sepuluh Nopember, Surabaya, Indonesia

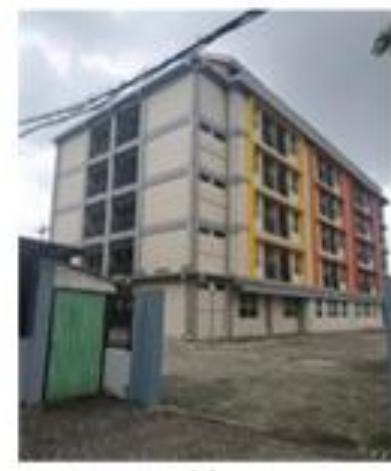

(a)
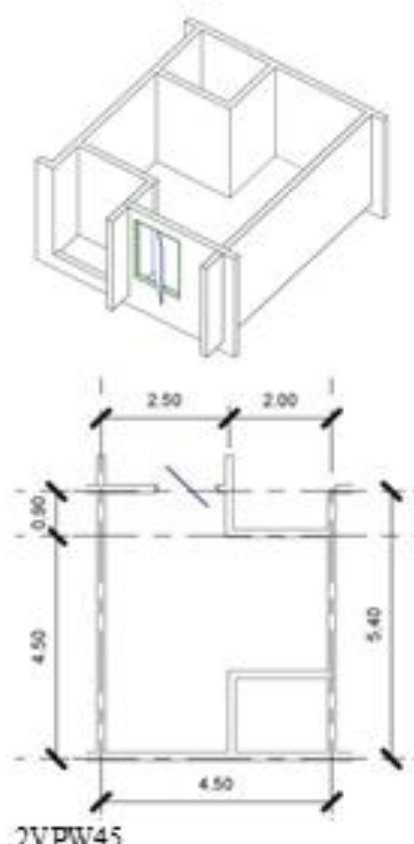

$2 \mathrm{VPW} 45$

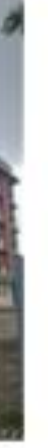
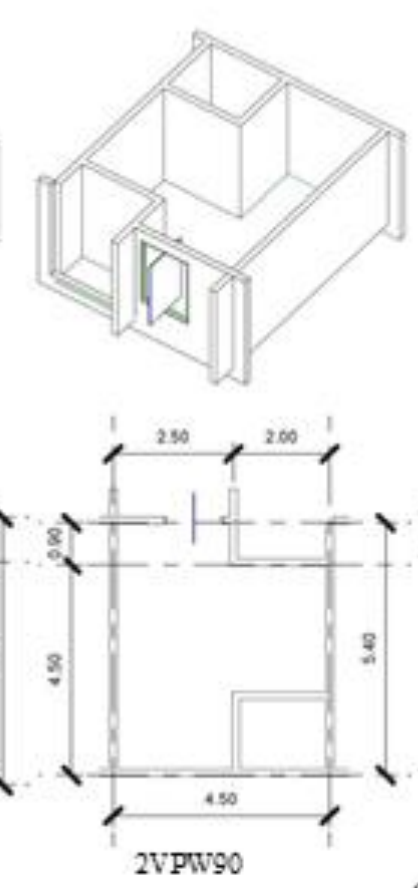

(b)

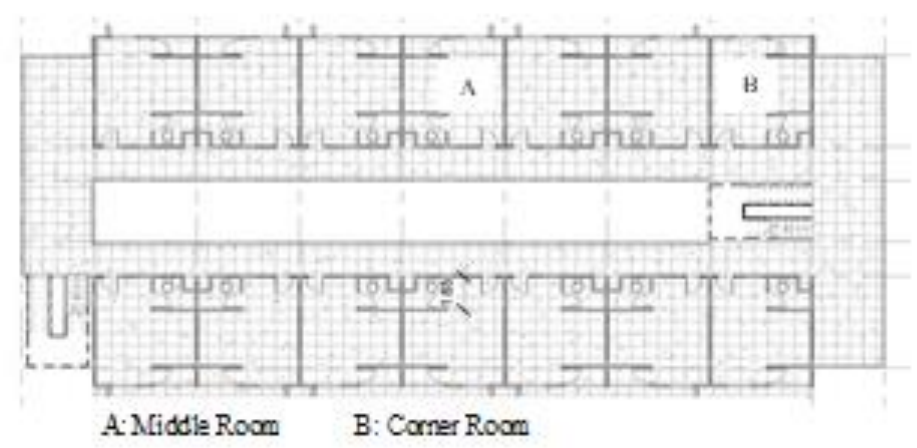

(b)
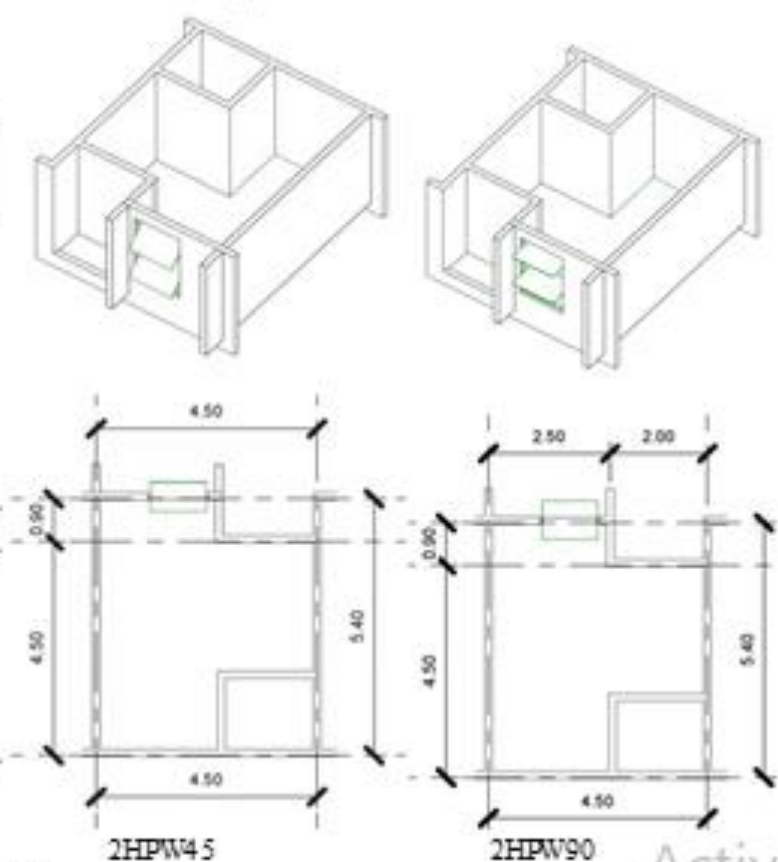

$2 \mathrm{HP} \times 45$

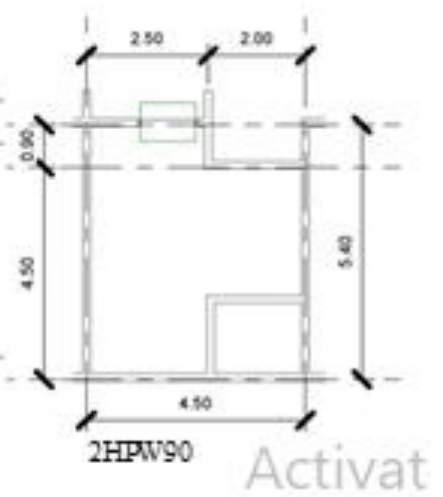

Figure 1. (a) Case Study and (b) Room Positions which reviewed, and experimental models.

different in the rooms in the middle and corner of the building. The units of rumah susun that reviewed were based on different positions in 5th floor can be seen in Figure $1 \mathrm{~b}$. Because the building form affects the distribution of pressure in the building facade so that it affects the indoor air velocity.

The proposed design of a combination of wing walls and pivot windows is the result of a literature study. The effect of window type on the performance of single sided natural ventilation was reviewed by air flow distribution and indoor air velocity. The horizontal pivot windows (HPW) and vertical pivot windows (VPW) show the best performance because the sash form slanted opening gap in front of opening and the inside the room [11]. The window opening angle considers the opening area of the window.

Meanwhile, the thickness of the wing walls applied in the study is $0.1 \mathrm{~m}$ and is equal to the normal thickness of the partition wall [12]. The depth of the wing walls considered by the study of Mak [13]. Thus, the depth of the wing walls used was half of the window width because the openings in this study are single openings. The wing wall design is wider than the wing walls in a case study building. In addition, the distance of the wing walls is closer than the distance of the wing walls in base case facade. Table 1 shows that there were four experimental models, namely a combination of wing walls design with a depth of $60 \mathrm{~cm}$ and pivot windows with 45 and 90 degrees opening angles.

\section{B. Research Methodology}

1) Verification Studies

Verification is conducted at three times by the same conditioning room between field measurements and simulations. Micro climate measurements used a weather station and conducted at 17 meters height from the ground surface. The difference between the results of measurements data and simulation results is still acceptable because the deviation value is not more than $0.5-1 \mathrm{~m} / \mathrm{s}$.

\section{2) CFD Settings and Parameters}

There are several studies on natural ventilation in residential buildings, these studies also use simulation programs in their research, especially CFD simulation programs. simulation using the Computational Fluids Dynamics program on ANSYS Academic 2020 software. CFD is able to investigate the parameters that affect natural ventilation and interactions between outdoor wind flow and indoor air flow. the combination of Autodesk Revit and Autodesk CAD software aims to shorten time with precise and neat model results that are acceptable to CFD software. Meshing applying non-uniform mesh due to the complexity 
The $6^{\text {th }}$ International Seminar on Science and Technology (ISST) 2020

July $25^{\text {th }} 2020$, Institut Teknologi Sepuluh Nopember, Surabaya, Indonesia
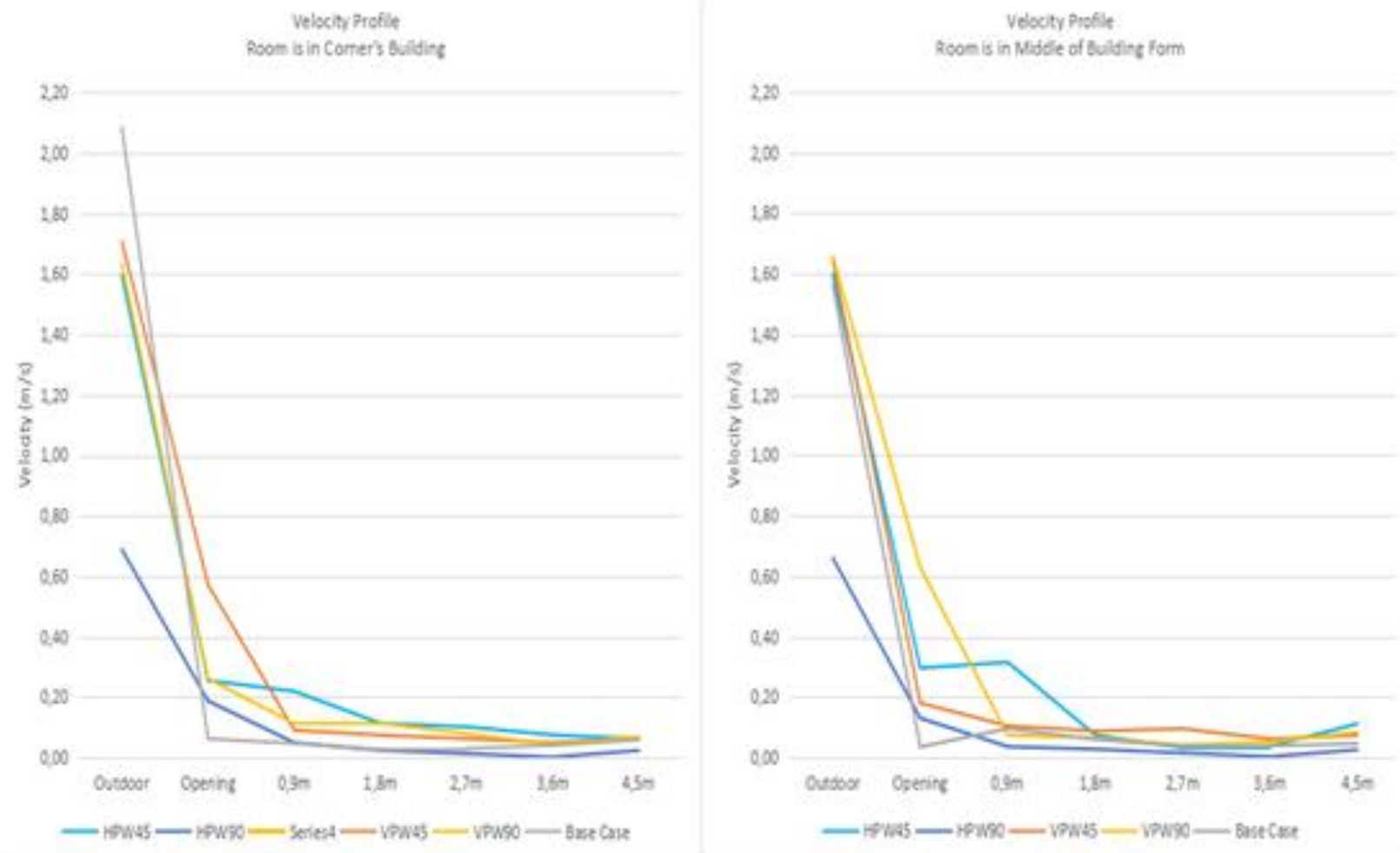

Figure 2. Velocity profile in (a) Corner rooms and (b) Middle room of the building form in oblique wind direction.

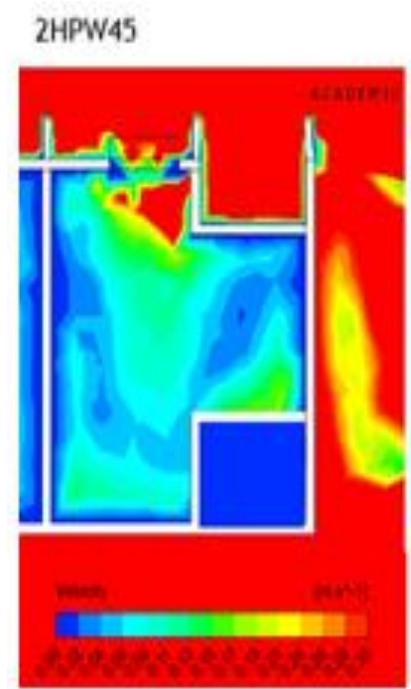

(a)
2VPW45

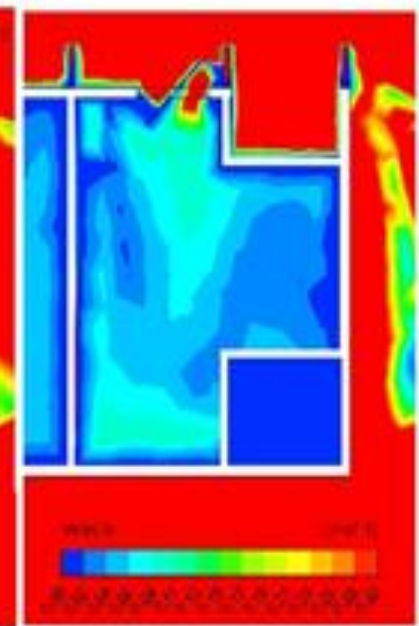

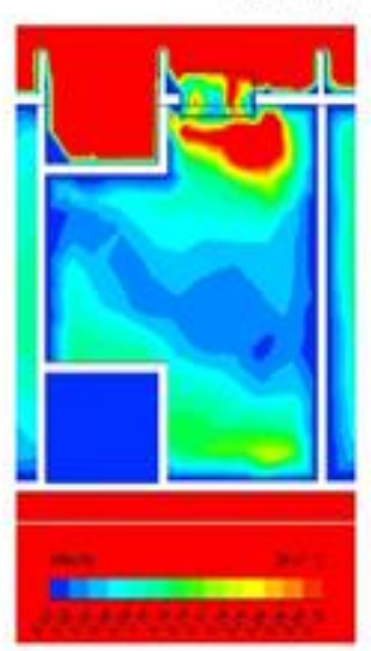

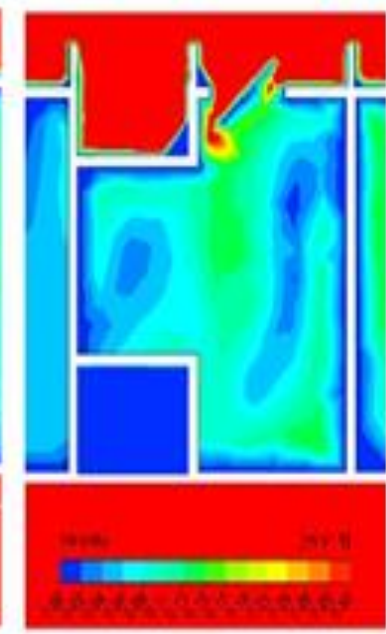

(b)

Figure 3. Contours of velocity in (a) Corner rooms and (b) Middle room of the building form in oblique wind direction.

of geometric shapes [8]. The turbulence model used is the turbulence model Renormalization group (RNG) k $\varepsilon$.Velocity input is the result of calculations using the Power Law equation. Simulastion's solution using the volume control method with the Semi-Implicit Method for PressureLinked Equations (SIMPLE) algorithm and Discretization settings using Second Order Upwind and First Order Upwind adjust to the level of complexity of the airflow volume on the model.

The single sided natural ventilation performance in this case study was reviewed by room positions in building form. That is room in building's corner and room in the middle of building form. Because air movement deflects over and around buildings, distinct air patterns are established. It formed a vortex at the ground and escapes around the building's corner [14]. So, the acquisition of wind is different in each room. The simulation is carried out to represent the condition at 12.00. This time was chosen because it represents a crucial condition where it is stated that air temperature reaches peak condition and humidity reaches low condition. So at that time, the presence of sufficient wind in the room is very necessary. The indoor air velocity data from the simulation results is taken at the human body level.

In this simulation studies, there were two wind direction conditions. The wind direction is from the West or formed an $90^{\circ}$ angle to the opening. This condition is represented the 
The $6^{\text {th }}$ International Seminar on Science and Technology (ISST) 2020

July $25^{\text {th }} 2020$, Institut Teknologi Sepuluh Nopember, Surabaya, Indonesia

condition when the wind direction is parallel to the opening. In second condition, wind direction was from the North West or formed an $45^{\circ}$ angle to the opening. This condition was represented the condition when the wind direction is oblique to the opening.

\section{RESULTS AND DISCUSSION}

\section{A. Indoor Air Velocity}

The average indoor air velocity is taken from the grid per $90 \mathrm{~cm}$ which represents the depth of room. Natural ventilation performance was reviewed by comparison of indoor air velocity between base case condition and modification conditions. The improvement of indoor air velocity was seen at Table 2. In the condition of the wind direction formed an 45 degrees angle to opening, the average indoor air velocity in the corner room has increased up to three times by applying the 2VPW45 model. Application of the 2HPW45 model in a corner room could increase indoor air velocity up to 0.138 $\mathrm{m} / \mathrm{s}$, while the $2 \mathrm{VPW} 45$ model could increase indoor air velocity up to $0.153 \mathrm{~m} / \mathrm{s}$. With an 90 degrees opening angle, the 2VPW90 model increased the indoor air velocity up to $0.114 \mathrm{~m} / \mathrm{s}$ in the corner room. While the 2HPW90 model did an insignificant increased.

When the wind direction is parallel to the opening, indoor air velocity is increased up to five times when applying 2HPW45 or 2HPW90 models. The 2HPW45 model increased indoor air velocity up to $507 \%$ and the 2HPW90 model increased indoor air velocity up to $395 \%$. Meanwhile, the 2 VPW45 model can increased indoor air velocity up to $340 \%$. Model 2VPW90 shows the best performance in a corner room in parallel wind conditions. The highest increases indoor air velocity was in corner room that reach up to $0.054 \mathrm{~m} / \mathrm{s}$. When the wind direction is parallel to the opening, the middle room is in the midstream and the corner is in the downstream. Therefore, the difference in pressure in the corner room is greater than in the middle room so that the indoor air velocity in the corner room is greater than in the middle room.

The performance of the model in the middle room of the building shows different results. In oblique wind conditions, the middle room of the building has increased significantly when applying the 2VPW90 model. The indoor air velocity in the middle room of the building shows three time increased when applying the 2VPW90 model and indoor air velocity reached $0,158 \mathrm{~m} / \mathrm{s}$. The highest increased of indoor air velocity was compared to other design proposals. However, with an 45 degrees opening angle, the 2HPW45 model shows an increased of indoor air velocity up to $276 \%$ and 2 VPW45 model increased indoor air velocity up to $192 \%$.

The performance of the model with an 45 degree opening angle shows a difference when the wind is parallel and oblique to the opening. The 2VPW45 model enhanced indoor air velocity up to $751 \%$ in the middle room of the building. While the 2HPW90 and 2VPW90 models can increased indoor air velocity by around $600 \%$. Indoor air velocity in the base case model is very small at $0.01 \mathrm{~m} / \mathrm{s}$. By applying the combination of wing walls and pivot windows, indoor air velocity shows the highest increase up to $0.072 \mathrm{~m} / \mathrm{s}$. The best performance is showed by a combination of wing wall models
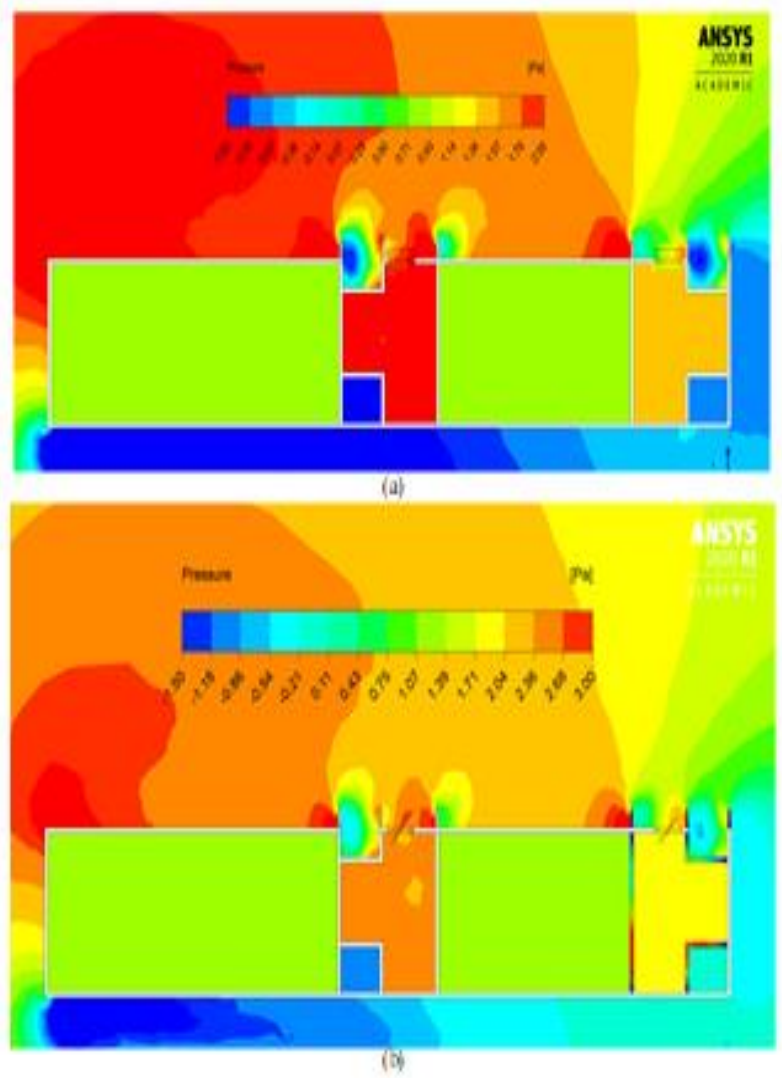

Figure 4. Contour of Pressure in (a) 2HPW45 models and (b) 2V PW45 models in oblique wind direction.

Table 1.

Experimental Design

\begin{tabular}{cccc}
\hline \hline $\begin{array}{c}\text { Wing } \\
\text { Walls }\end{array}$ & \multicolumn{2}{c}{ Pivot Windows } & Models \\
\hline & $\begin{array}{c}\text { Type of } \\
\text { Windows }\end{array}$ & $\begin{array}{c}\text { Opening } \\
\text { Angle }\end{array}$ & \\
\hline With & & & \\
Wing & HPW & 45 & 2HPW45 \\
Walls & & & 2VPW45 \\
& VPW & 45 & 2HPW90 \\
& HPW & 90 & 2VPW90 \\
\hline \hline
\end{tabular}

and vertical pivot windows. The effectiveness of the opening angle in the pivot windows depends on the direction of the wind and the location of the room.

\section{B. Indoor Air Distribution}

The Figure 2 shows simulation results in oblique wind conditions. It shows that model 2.HPW45 can constantly reached the depth of room in corner room can be seen in Figure $2 \mathrm{a}$ and model 2VPW45 could constantly reach the depth of room in middle of the building in Figure $2 \mathrm{~b}$. The contours of 2HPW45 shows that the distribution air flow in corner room could reach the best performance when applied combination of wing walls and HPW models with $45^{\circ}$ angle opening in Figure 3a. Meanwhile, the distribution air flow in middle room could reach the best performance when applied combination of wing walls and VPW models with $45^{\circ}$ angle opening can be seen in Figure $3 \mathrm{~b}$.

Figure 4 a shows the contour of pressure around building in oblique wind direction. The indoor air velocity in room is caused by differences in pressure outside and inside the room. 2HPW45 distributed airflow evenly in the corner room because the pressure difference reached $0.86 \mathrm{~Pa}$ in the corner 
The $6^{\text {th }}$ International Seminar on Science and Technology (ISST) 2020

July $25^{\text {th }} 2020$, Institut Teknologi Sepuluh Nopember, Surabaya, Indonesia

Table 2.

Comparison of Indoor Air Velocity between Base Case Condition and Modification Conditions

\begin{tabular}{|c|c|c|c|c|c|c|c|c|c|c|c|}
\hline Corner Room & $\begin{array}{l}\text { Base } \\
\text { Case }\end{array}$ & 2HPW45 & 2HPW90 & $\begin{array}{c}2 \mathrm{~V} \\
\mathrm{PW} 45 \\
\end{array}$ & $\begin{array}{c}2 \mathrm{~V} \\
\text { PW90 }\end{array}$ & Corner Room & $\begin{array}{l}\text { Base } \\
\text { Case }\end{array}$ & 2HPW45 & 2HPW90 & $\begin{array}{c}2 \mathrm{~V} \\
\mathrm{PW} 45\end{array}$ & $\begin{array}{c}2 \mathrm{~V} \\
\mathrm{PW} 90 \\
\end{array}$ \\
\hline $\begin{array}{c}\text { Average } \\
\text { Velocity }(\mathrm{m} / \mathrm{s})\end{array}$ & 0,0446 & 0,1384 & 0,1270 & 0,1531 & 0,1138 & $\begin{array}{c}\text { Average } \\
\text { Velocity }(\mathrm{m} / \mathrm{s})\end{array}$ & 0,0099 & 0,0504 & 0,0392 & 0,0338 & 0,0536 \\
\hline $\begin{array}{c}\text { Rate of } \\
\text { Increment }(\Delta \%)\end{array}$ & - & $311 \%$ & $285 \%$ & $343 \%$ & $255 \%$ & $\begin{array}{c}\text { Rate of } \\
\text { Increment } \\
(\Delta \%)\end{array}$ & - & $507 \%$ & $395 \%$ & $340 \%$ & $539 \%$ \\
\hline Middle Room & $\begin{array}{l}\text { Base } \\
\text { Case }\end{array}$ & 2HPW45 & 2HPW90 & $\begin{array}{c}2 \mathrm{~V} \\
\text { PW45 }\end{array}$ & $\begin{array}{c}2 \mathrm{~V} \\
\text { PW90 }\end{array}$ & Middle Room & $\begin{array}{l}\text { Base } \\
\text { Case }\end{array}$ & 2HPW45 & 2HPW90 & $\begin{array}{c}2 \mathrm{~V} \\
\text { PW45 }\end{array}$ & $\begin{array}{c}2 \mathrm{~V} \\
\mathrm{PW} 90\end{array}$ \\
\hline $\begin{array}{c}\text { Average } \\
\text { Velocity }(\mathrm{m} / \mathrm{s})\end{array}$ & 0,0524 & 0,1447 & 0,1790 & 0,1008 & 0,1578 & $\begin{array}{c}\text { Average } \\
\text { Velocity }(\mathrm{m} / \mathrm{s})\end{array}$ & 0,0096 & 0,0401 & 0,0654 & 0,0722 & 0,0596 \\
\hline $\begin{array}{c}\text { Rate of } \\
\text { Increment }(\Delta \%)\end{array}$ & - & $276 \%$ & $342 \%$ & $192 \%$ & $301 \%$ & $\begin{array}{c}\text { Rate of } \\
\text { Increment } \\
(\Delta \%)\end{array}$ & - & $417 \%$ & $681 \%$ & $751 \%$ & $620 \%$ \\
\hline
\end{tabular}
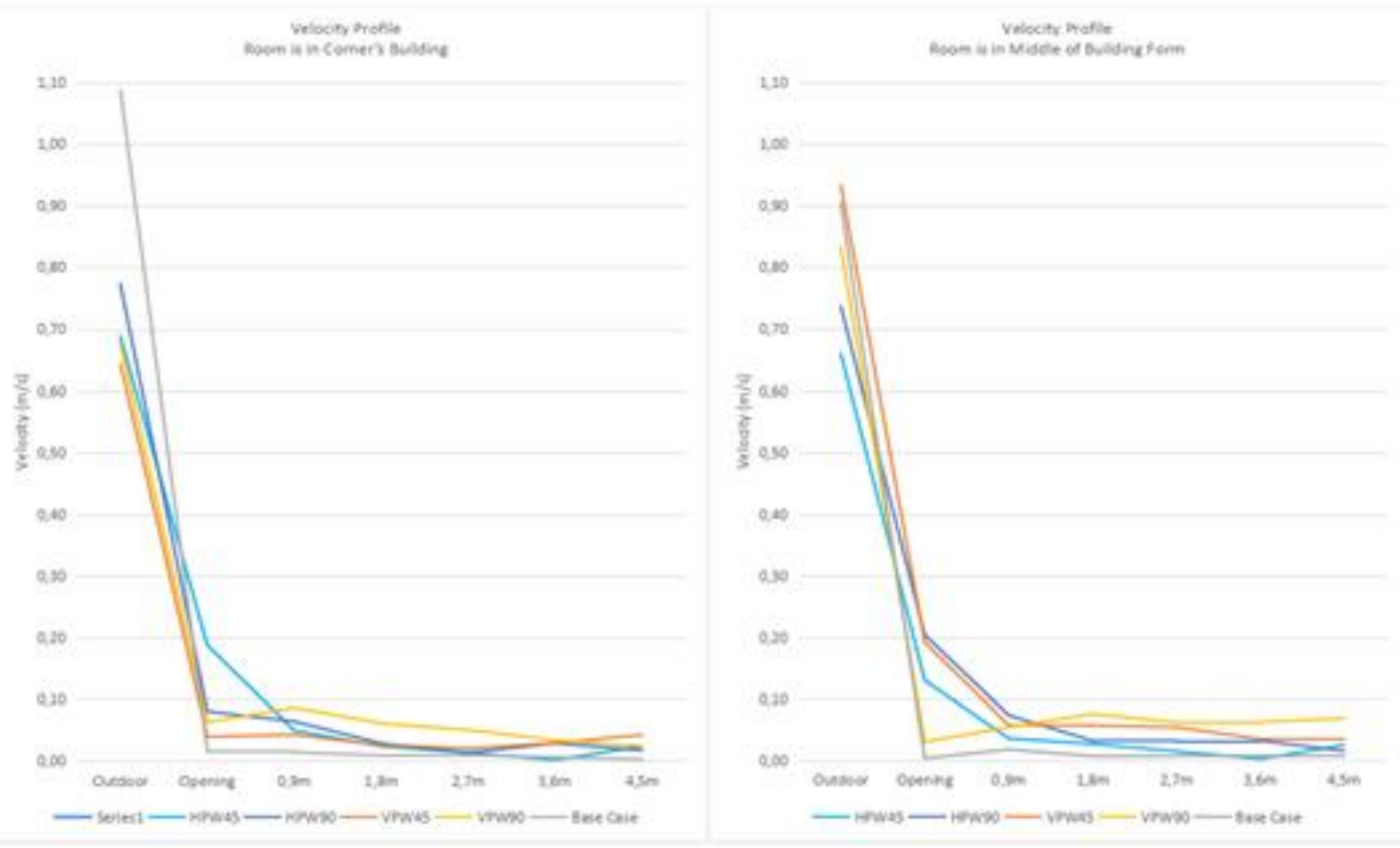

Figure 5. Velocity profile in corner rooms and middle room of the building form in parallel wind condition.

room while in the middle room only reached $0.21 \mathrm{~Pa}$. Model 2VPW45 distribute airflow evenly in the middle room because the pressure difference reaches $0.6 \mathrm{~Pa}$ in the middle room while in the corner room only reaches $0.3 \mathrm{~Pa}$ in Figure $4 b$.

In the condition of the wind direction forming an angle of 90 degrees or parallel to the openings, the 2VPW90 model shows the best performance in distributing airflow into room in Figure 5. This happened to the room in the corner and the room in the middle of the building. The contours shows that the distribution air flow in both corner and middle room could reach the best performance when applied VPW models with $90^{\circ}$ angle opening can be seen in Figure 6. Model 2VPW90 distributed air flow evenly because there is a role of sash that directed the air flow into the room. The application of wing walls helped to catch the wind even though the air pressure is negative can be seen in Figure 7.

\section{CONCLUSION}

Experimental studies on the performance of a combination of wing wall designs and pivot windows show several effects of model variables on the performance of single sided natural ventilation in rumah susun, including:

1. Applying combination of pivot window and wing wall for façade demonstrate better performance compared to that of the base case. It is resulted by the blade angle, which direct the air movement.

2. In parallel wind direction, 2VPW90 shows the best performance with increased indoor air velocity up to five times in corner room. In middle room, 2VPW45 shows the best performance and increased indoor air velocity up to seven times. So that the opening angle can help improve ventilation performance when considering wind direction and room location. In oblique wind direction, 2HPW45 and 2HPW90 increased indoor air velocity up to three times in middle room. As well as 2VPW45 model in corner room and 2VPW90 models in middle room that increased indoor air velocity up to three timers. So, the 45 opening angle in corner room and 90 opening angle in middle room increased the indoor air velocity three times than base case condition.

3. This study supports the results of research that conducted by Wang in 2018 in studied the performance of windows type on single-sided natural ventilation [7]. The 
The $6^{\text {th }}$ International Seminar on Science and Technology (ISST) 2020

July $25^{\text {th }}$ 2020, Institut Teknologi Sepuluh Nopember, Surabaya, Indonesia

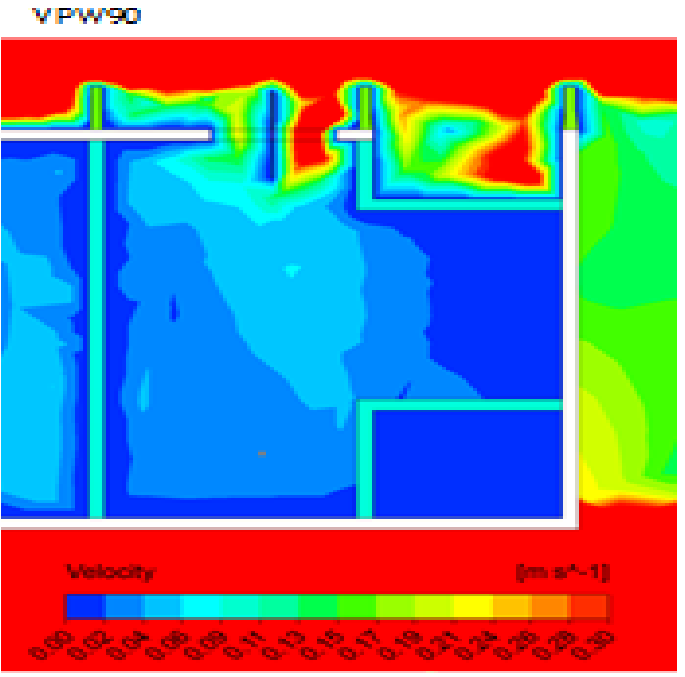

(a)

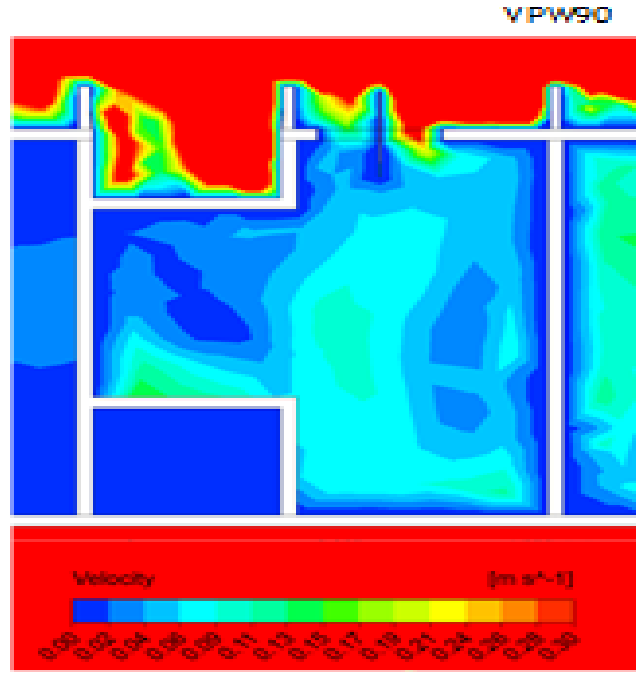

(b)

Figure 6. Contours of velocity in (a) Corner rooms and (b) Middle room og the building form in parallel wind condition.

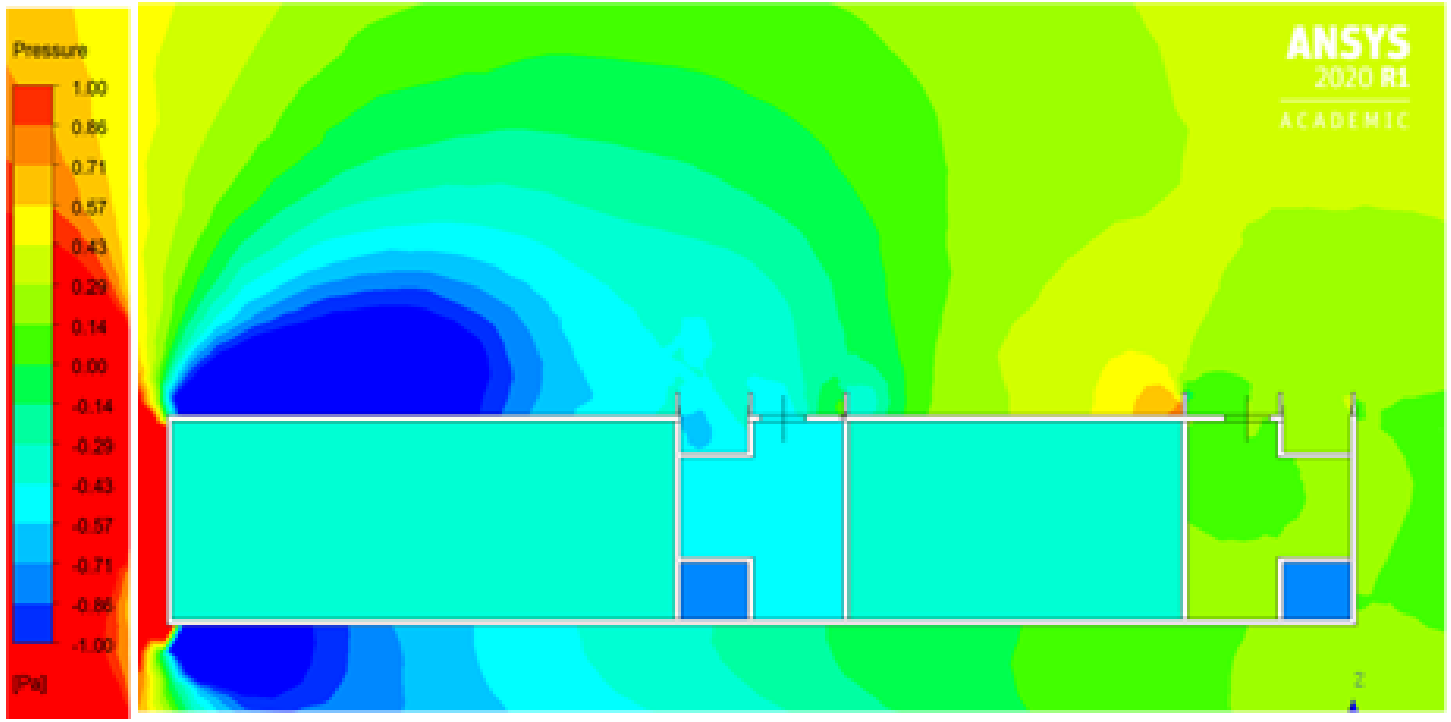

Figure 7. Contour of pressure in (a) 2HPW45 models and (b) 2V PW45 models in oblique wind direction.

distribution of air flow in a room is influenced by the pressure difference between the outdoor and indoor condition. Models with different opening angles will produced pressure differences. The Vertical Pivot Window shows the best performance in corner room with both wind direction condition. Because the sash can help to improve pressure differences while applied to the wing walls. Meanwhile, in middle room, Horizontal Pivot Windows shows the best performance in oblique wind directions. In the parallel wind directions, Vertical Pivot Windows shows the best increased the indoor air velocity.

\section{REFERENCES}

[1] Passe, U., Battaglia, F., Designing spaces for natural ventilation : an architect's guide, New York and London:Taylor and Francis Group, 2015.

[2] Allard, F., Ghiaus, C., Natural ventilation in the urban environment : Assessment and design, Repr. ed. London, 2005.

[3] Mufidah, F.M., Benny Bintarjo DH, Hanny Chandra Pratama, Yunantyo Tri Putranto, "Studi Fasade Rumah Susun Untuk Optimasi Energi Alam Pada Bangunan Di Tropis Lembab,” Universitas Wahid Hasim, Semarang, 2016.
[4] Rachmawati, F., Soemitro, R., "Low Cost Apartment Program Implementation in Surabaya Metropolitan Area," Procedia Engineering Vol.125," 2016, pp. 75-82

[5] Sari, A.A., Shirleyana, Feliciani, F.A., "Optimalisasi Kualitas Visual pada Rumah Susun di Indonesia", Temu Ilmiah IPLBI, Vol. D, 2016, pp. 073-080.

[6] Arethusa, M., Kubota, T., Murti, N., Agung., Nastiti, S,. N Antaryama, Gusti., Uno, T., "Factors Influencing Window Opening Behavior in Apartments of Indonesia," Hirosima University, Hirosima, 2014.

[7] Wang, Jihong; Wang, Shugang; Zhang, Tengfei; Battaglia, Francine., "Assessment of single-sided natural forces ventilation driven by buoyancy through variable window configurations," Energy and Buildings Vol. 139, 2017, pp. 762-779.

[8] Shi, Shanshan; Li, Hongjian; Ding, Xuw; Gao, Xin., "Effects of household features on residential window opening behaviors: A multilevel logistic regression study," Building and Environment Vol. 170, 2020, 106610.

[9] Tong, S., Wong, N.H., Tan, E., Jusuf, S.K., "Experimental study on the impact of facade design on indoor thermal environment in tropical residential buildings," Building and Environment. Vol 166, 2019, 106418.

[10] Givoni, Baruch., Man, Climate and Architecture, London: Applied Science Publisher ltd, 1976.

[11] Mak, C.M,. Niu, J.L., Lee, C.T., Chan, K.F., "A numerical simulation of wing walls using computational fluid dynamics," Energy and Buildings Vol. 39, 2007, pp 995-1002. 
IPTEK Journal of Proceedings Series No. (6) (2020), ISSN (2354-6026)

The $6^{\text {th }}$ International Seminar on Science and Technology (ISST) 2020

July $25^{\text {th }} 2020$, Institut Teknologi Sepuluh Nopember, Surabaya, Indonesia

[12] Ghadikolaei, F.M., Ossen, D.R., Mohamed, M.F., "Effects of wing wall at the balcony on the natural ventilation performance in medium-rise residential buildings," Journal of Building Engineering. Vol. 31, 2020, pp 101-316.

[13] Nejat, Payam, dkk., "Evaluation of a two-sided windcatcher integrated

with wing wall (as a new design) and comparison with a conventional windcatcher," Energy and Buildings. Vol 126, 2016, pp 287-300

[14] Boutet, T. S., Controling Air Movement A Manual for Architects and Builders, United State of America: McGraw-Hill Book, 1987. 